\title{
Multiple Use in the Man-Made Forest
}

\author{
by
}

\author{
T.G. Jeanes, RPF ${ }^{2}$
}

\section{Introduction}

It is appropriate that foresters in the transition from the wild cut to the regulated cut to the establishment of the manmade-forest have discovered the multiplicy of resources generated from forest land. The public have told us that they want their land managed for timber, range, recreation, fish, water and wildife. In view of this, and the fact that they own $95 \%$ of the forest land in British Columbia, we had better listen. Forests must be looked upon not simply as a collection of trees but rather as a complex of plants and animals from soil micro-organisms to tall timber, all of which to a greater or lesser degree is interdependent on each other.

Multiple resource-use has been defined as "the deliberate and careful planning of the integration of various resource uses to interfere with each other as little as possible and to complement each other as much as possible.

Some prefer to add "giving due regard to the order of importance of each use in a particular area in an attempt to achieve the optimum social and economic benefit to society". We can debate the degree of social benefit from the ecological or 'web of life' to the religious or philosophical concerns but there can be no debate that the integration of forest land resources must be considered desirable if we are to achieve the Public's stated goal.

\section{Balco's Stage}

Our Company, Balco Industries Ltd., is a Canadian owned public Company. We operate three sawmills, two veneer plants and one plywood plant complete with barking. chipping, sawdust and hog recovery systems. We further hold a $50 \%$ interest in a cedar sawmill and a $50 \%$ interest in a forest seedling nursery and seed orchard complex. We conduct operations over some 700000 hectares of Crown land from which a multitude of benefits flow. In excess of 1 million $\mathrm{m}^{3}$ of timber is harvested from roughly 4800 ha per year. Thus our activities not only have a major influence on these lands but also have a significant impact on the social and economic fabric of the area.

We are not involved with the public and integrated use issues for the good of our health - rather, we sincerely believe and have proven that the Company as well as other resource users benefit from this practice. These people are

This paper was presented at the Technical Session: The Creation, Care and Use of the Man-Made-Forest at the Annual Meeting of the CIF, Victoria, B.C. September 1986

2 Vice-President Woodlands, Balco Industries Ltd., Kamloops, B.C. V2C 5 K 1 our neighbours and Balco Industries Ltd. has had a good deal of success in recognizing and accommodating their resource uses in our operating areas by working together.

This diverse, biogeoclimatic region is endowed with agriculture, domestic grazing, forests, fish, wildlife and outdoor recreation opportunities, as well as watersheds that regulate the quality and quantity of water. It is a complex environment - interfacing with the cities of Kamloops, Merritt and satellite communities (population \pm 100000 ). It is transected by two major highways, two national railroads, two major pipelines and many powerlines, phonelines and secondary roads. It is further broken by substantial private land holdings, Indian reserves, mineral claims and active mines. Ranchers seasonally range some 25000 head of livestock on the forested Crown land; irrigation districts store thousands of acre/feet of water behind some 173 storage dams and network miles of creeks and ditches to irrigate their crops; there are seven established ski hills, heli-skiing areas and restricted areas for cross-country skiing, snowmobiling, motorbikes and ATV's. There exists 34 private fishing resorts, some \pm 300 undeveloped fishing lakes, many guides, outfitters and trappers; 12 lakes developed for summer home sites, even lakes for ice-racing motorcycles and such activities as the McQueen Lake environmental centre. Thousands of kilometers of roads are used by loggers, ranchers, miners, trappers, woodcutters, fishermen, hunters, hikers, berry pickers and recreationists. All of these users have been accommodated on a rational basis and we co-exist on the same land base knowing that we (collectively) have foregone some growth and yield opportunities to protect and enhance other resource uses for the greatest common benefit.

We participate in 17 co-ordinated Resource Management Plans covering 500000 hectares, five Resource Folios - 120000 hectares, one Moratorium encompassing 33000 ha of wilderness, two Timber Supply Area Plans covering 3200000 hectares and four Deferred Crown Land Plans encompassing 310000 ha under the jurisdiction of the Ministry of Forests and Lands. We are further involved in two Watershed Basin Plans through the Ministry of Environment and one Official Settlement Plan devised by the Thompson Nicola Regional District all of which overlap one or the other to some degree. We are active on working committees, task forces, planning groups, steering committees and public advisory committees. Within this framework we harvest 1 million $\mathrm{m}^{3}$ per year ranging from selectively cut Douglas-fir and Ponderosa pine through species admixtures to clearcut lodgepole pine on plateaus and clearcut as well as residual logging in sub-alpine fir and Engelmann spruce at high 
elevations. We also harvest some coastal hemlock-balsam in the south and wet belt cedar-hemlock in the north. The foregoing simply demonstrates that the work area is complex, that multiple-use is now taking place and we recognized that these activities will accelerate in the future.

\section{Balco's Program}

Today we use innovative silvicultural systems, sophisticated logging equipment and diverse engineering programs to sustain the integrity of the ecosystems that generate this abundant wealth. Multiple-uses that require we accept something less than maximum timber production are not necessarily in conflict with timber management. However, if we are to be successful in accommodating these demands we can no longer tolerate current overstocking, imbalanced age class structures, poor species composition, noncommercial, decadent and cull forests, not-sufficientlystocked land or past and present fire, insect, disease and grazing damage. This most valuable multiple resource land base is capable of producing a compatible yield of timber far in excess of that required to accommodate other users, however, stressing only timber capability ignores integrated use and lacks the holistic perspective that the public demands. If we are to discourage land alienation for single use purposes and maintain our credibility it is essential that we practice holistic management of forest land resources. We have the mandate to ensure the desirable mix of products flows from the forest, all we need now is the will to accomplish the task.

This does not have to be an expensive exercise and more often than not communicating the objectives has created a consciousness on the part of the woods crews which has led to innovative means of achieving better results with less cost. We have successfully enhanced multiple-use productivity by:

- altering cut block size and patterns to facilitiate wildlife feeding habits increasing edge effects and using type boundaries;

- reserving corridors to enhance wildlife management:

- designing snag management programs to harbor nongame and cavity nesting birds:

- improving habitats by clearing deciduous cover to encourage shrub growth and leaving adjacent shelter belts for bedding down area;

- allowing the Wildlife branch to plant willow on cut-blocks encompassing critical winter range and breeding areas;

- logging dense, decadent stands of lodgepole pine, spruce and alpine fir where windfall impedes animal travel and overstory annihilates browse

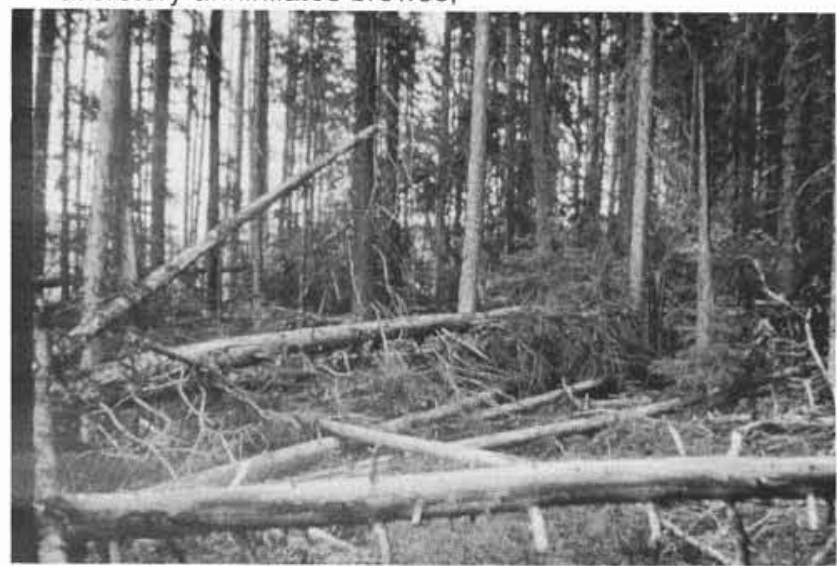

Figure 1. Overmature lodgepole pine. Stands such as this have negative growth. Windfall plus an understory of alpine fir inhibit animal movement, kill forage and browse species, and make recreation impossible. These stands must be replaced
- designing cut-blocks to avoid cool zones, alder/willow swamps \& favoured lake shores;

- preserving cover on south facing slopes while opening up north facing slopes;

- preserving old growth on rock bluffs for shelter and feed;

- instituting a "fallers' selection" logging system in conjunction with a quality thinning program thereby increasing the moisture and sunlight available for tree growth, forage and browse;

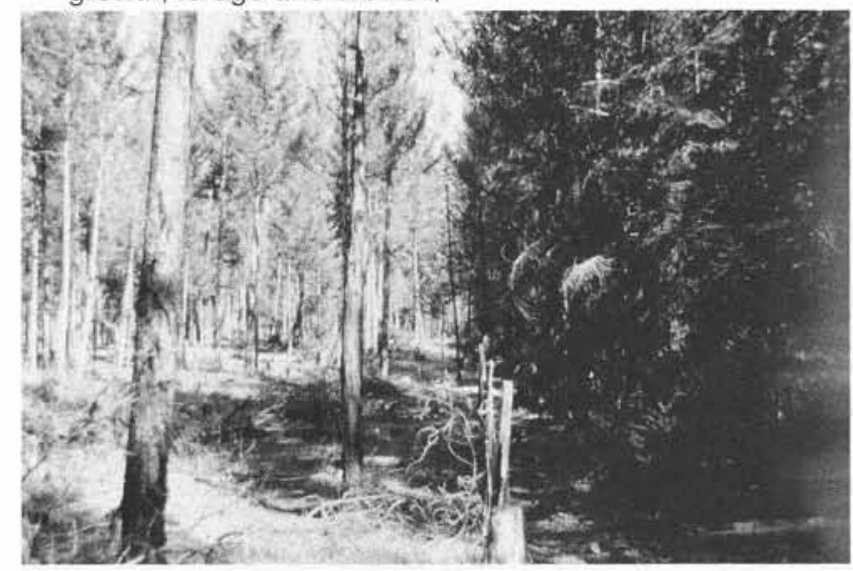

Figure 2. A "fallers' selection" logging of Douglas-fir followed by thinning of non-merchantable thickets to create wellspaced multi-story uneven-aged stand, resulting in better browse, better forage for livestock, enhanced recreation and greater tree growth. Note density of natural stand.

- placing machine reserves around swamps to enhance the nesting area for migratory birds;

- not logging some areas of critical wildlife habitat;

- installing proper culverts and ditches to avoid the siltation of spawning streams;

- keeping equipment out of fish streams:

- leaving streamside reserves to filter run-off and protect fish; and

- installing bridges rather than culverts to maintain spawning beds.

Similarly we have aided the agro-forest users by:

- avoiding breeding pastures, ensuring proper cattle guard construction, repairing fences, brushing out drift fences, creating and protecting water holes;

- co-operating with the Ministry of Forests and Lands and the range user in site preparation methods and seeding of clearcut cut-blocks with domestic forage;

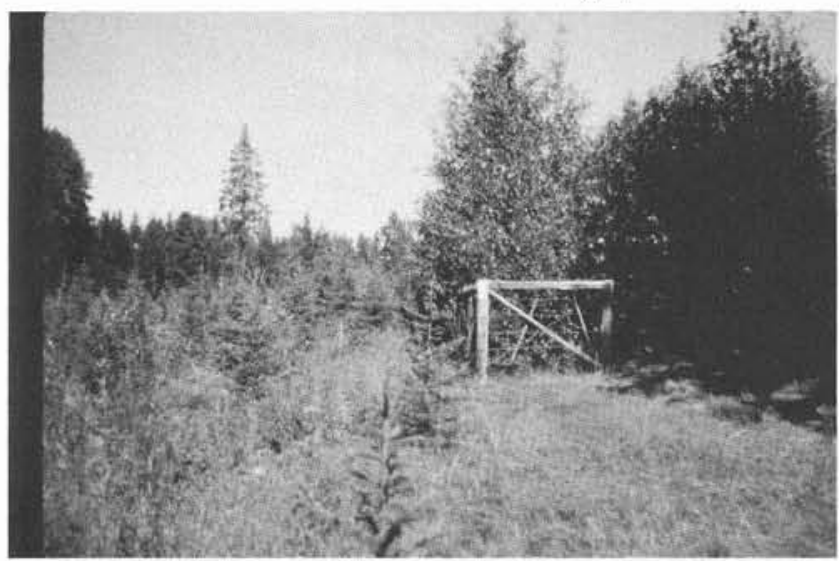

Figure 3. Enclosure within spruce plantation that was seeded with forage plants. Note the brush control performed by cattle versus the brush-choked enclosure where cattle did not graze. 
- ripping up landings and secondary roads to restrict access and increase forage area;

- seeding right-of-ways, landings, skid trails and secondary roads to tame grasses; and

- juvenile spacing, thinning and "fallers selection" logging systems to open up stands allowing more moisture and sunlight to enhance forage as well as forest growth.

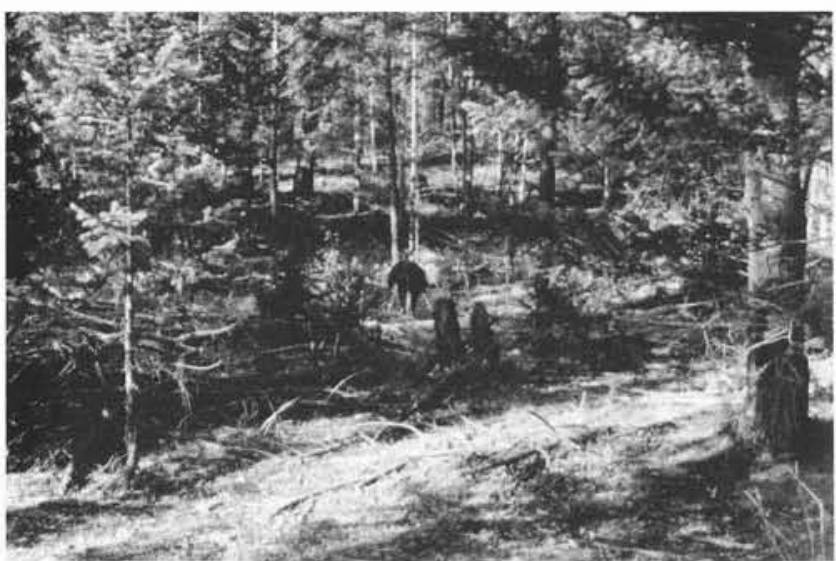

Figure 4. Cattle foraging in recently logged Douglas-fir forest. Fallers' selection logging was followed by thinning to create a well-stock vigorous residual stand, which will be harvested every 20 years to maximize growth and minimize canopy closure.

by:

We have further enhanced the water and recreation uses

- limiting the harvest in any one watershed at a particular time to maintain water quality and quantity;

- leaving reserves along creeks and lake shores to filter runoff, maintain aesthetics, provide cool zones and preserve recreation:

- protecting water intakes, storage dams, gates spillways and constructing proper ditches, bridges, culverts, water bars, etc

- using "fallers' selection" logging systems to maintain aesthetics and reduce the interception of precipitation thereby increasing the snowpack and delaying the run-off while enhancing the recreational use by bikers, hunters, skiers, hikers, snowmobilers, all terrain vehicle users and even firewood cutters;

- designing cutblock patterns to complement the architecture of the landscape thereby maintaining the integrity of visual aesthetic site zones:

- maintaining roadside reserves and buffer strips to protect aesthetics, recreation values, fishing camps and historic trails;

- controlling access to recreation sites to ensure a mix of walk-in, drive-in experiences and protect fishing camp operators; and

- providing recreation sites adjacent to streams and lakes where access fosters public use.

While the foregoing generally complement the productivity of other resource users we devised mechanisms to avoid future problems:

- high lead logging systems to minimize erosion and utilize that steep slope portion of the land base;

- back-hoe road construction and better drainage systems along with seeding rights-of-way to enhance soil stability and accommodate peak storm flows;

- selection logging as well as two and three pass logging systems to lessen impact and perpetuate the variety of uses over the rotation;
- planned programs such as trap trees for forest insect control (phased falling, etc.);

- salvage logging of blowdown, insect infested and diseased stands to reduce future impact;

- forest fire protection planning and continuous monitoring of endemic insect populations:

- helicopter tree seed collections to ensure seedlings will be available for the areas we shall want to harvest in the future:

- construction of a forest nursery to ensure the availability of seedlings and prompt reforestation of the cut-overs:

- establishment of seed orchards and progeny trials to enhance future growth and yield; and

- research programs to facilitate timber growth and yield and maximize opportunities for other resource users.

These are some of the mechanisms being used to handle particular circumstances but in our operations at least as much time is given to the concerns of other resource users as is spent on timber acquisition, extraction and replacement. Given this environment we have worked diligently to provide the stewardship that ensures resource uses are well integrated. The following example demonstrates what can be accomplished through integration with the support of many individuals and agencies.

\section{Community Lake}

In 1962 Balco was awarded cutting rights to 120 ha of lodgepole pine and spruce-balsam in the Community Lake area north of Kamloops. From personal experience I can verify that you could walk through this stand on dead and down trees all day and never touch the ground. That is fact - there was no grazing, no wildlife, no recreation and no timber production.

The area was roaded, logged, burned and in 1971 planted to trees. Because of a controversy concerning the grass/tree interface the area was seeded to grass the winter following planting and designated as a study area. The area was fenced into three 40-ha pastures, cattle weighed in and out, grass clippings made to determine yields and nutritive values measured.

\section{Results 15 Years Later}

- the plantations of lodgepole pine and spruce have a $90 \%$ survival rate which is conservatively estimated to yield 2 $\mathrm{m}^{3} / \mathrm{ha} / \mathrm{yr}$ with actual yield expected to be $8 \mathrm{~m}^{3} / \mathrm{ha} / \mathrm{yr}$ but sample plots have not been remeasured. At $\$ 200 / \mathrm{m}^{3}$ (Jones, 1986) the timber yield is conservatively contributing an economic benefit of $\$ 48000 / y$ r. The planted trees are growing much faster and better than the original stand of fire origin.

- the forage has produced 1 kilo of beef/ha/day for 100 days each year or at $\$ 2 /$ kilo $\$ 24000 / y r$.

- the mule deer and moose population now sustain a harvest of 30 and 6 animals, respectively, with an estimated value of 25 hunting days per animal at $\$ 30 /$ day or $\$ 27000 / \mathrm{yr}$.

- the value of fishing recreation has grown from zero to 5000 fishing days/yr on Community and Devick Lakes with an estimated value of $\$ 21 /$ day or $\$ 105000 / \mathrm{yr}$.

- the irrigation district has maintained and raised the dams increasing the water storage and creating further values from expanded hay crops.

Conservatively the identifiable benefits of this integrated productivity and development attributable to our access and logging add up to some $\$ 200000 / \mathrm{yr}$ to the people of British 
Columbia. Even if we subtract the fishing recreation due to its being a product of road access rather than land productivity the number would still be $\$ 100000 / y r$. Not bad for a small (120 ha) block that represents just one amoung hundreds of similar areas on which integrated use is being practiced to the benefit of British Columbians.

The foregoing demonstrates that to properly measure the return on investment, the value of integrated forest land management must be considered as the sum of the timber yield + agriculture yield + wildlife yield + recreation yield + water yield + whatever other values are generated on site. The uses may be simultaneous or sequential and we may need research to evaluate relative costs and net benefits, but all uses must be considered as desired and none must be overlooked. To manage for timber alone only reinforces the arguments of those who suggest that forests are too valuable to be entrusted to foresters. Similarly those who suggest that intensive forest management be directed at only the most productive sites ignore the economic benefits of multiple-use as well as the goals demanded by the public. Management of a poor site will often yield higher returns for a given investment than a good site. Certainly a community watershed, poor site or otherwise, would command as much management input as would a remote but highly productive site elsewhere. If you think not - just tell the public that you are going to log in their watershed but the site doesn't warrant intensive management activities.

So further to devoting much time and our best efforts to make integration work how do we deal with this multiplicity of activity.

\section{First}

You must have the will to establish objectives that maintain the diversity as well as enhance the productivity of shared resources. The objectives should minimize the impact on other resource users and be backed by professional, moral and financial committments

\section{Second}

You must assemble the accumulated knowledge of the disciplines involved and be in possession of a clear and holistic picture of the facts. The mandatory referral system of management and working plans helps foresters identify the values and concerns of the various government ministeries.
Third

You must communicate with other users. Use personal contact and field trips. Participate in meetings of livestock associations, co-ordinated resource management and folio plans, fishing camp associations, fish \& game clubs, irrigation districts, nature clubs, and ATV organizations. Contact summer home owners and the myriad of other concerned groups to identify their concerns and get their support and understanding.

\section{Fourth}

You must establish credibility and mutual trust by demonstrating that the integration of resource use can be practiced to the benefit of all users. Pick an area and try it, but remember - there are no simple answers or easy solutions to complex problems - only intelligent choices.

\section{Finally}

I submit that multiple-use in the man-made-forest is being practiced and people are involved to a far greater extent than the public realizes. Today our operating area alone hosts more recreationists than can be found in most designated parks or wilderness areas and the multiple-uses of the forest land base are optimizing the social and economic benefits to society. How many of our critics have established these facts or witnessed this reality?

\section{References}

Jones, Russell. 1987. Economic benefits of timber and productive forest land. For. Chron. 63: 112-118.

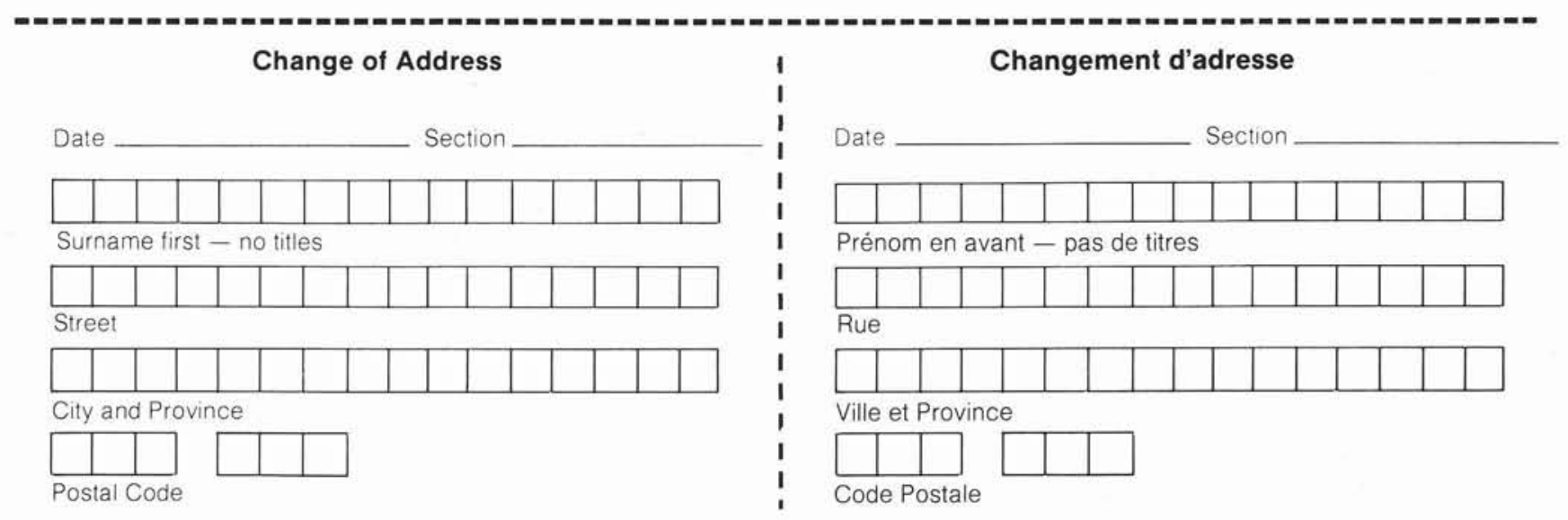

